\begin{tabular}{|l|l|l||}
\hline \multicolumn{2}{|c|}{ PublisherInfo } \\
\hline \hline PublisherName & $:$ & BioMed Central \\
\hline \hline PublisherLocation & $:$ & London \\
\hline \hline PublisherImprintName & $:$ & BioMed Central \\
\hline \hline
\end{tabular}

Articles selected by Faculty of 1000: chromosome pairing in Arabidopsis; hybrid inviability in birds and mammals; endogenous siRNAs in Arabidopsis; evolution of sex-biased genes in Drosophila; human patterns of genetic variation

\begin{tabular}{|l|l|l||}
\hline \multicolumn{2}{|c|}{ ArticleInfo } \\
\hline \hline ArticleID & $:$ & 3500 \\
\hline \hline ArticleDOI & $:$ & $10.1186 /$ gb-2004-5-12-360 \\
\hline \hline ArticleCitationID & $:$ & 360 \\
\hline \hline ArticleSequenceNumber & $:$ & 18 \\
\hline \hline ArticleCategory & $:$ & Paper report \\
\hline ArticleFirstPage & $:$ & 1 \\
\hline \hline ArticleLastPage & $:$ & 3 \\
\hline \hline & $:$ & RegistrationDate : 2004-11-5 \\
ArticleHistory & $:$ & OnlineDate $\quad: 2004-11-5$ \\
\hline
\end{tabular}




\begin{tabular}{|l|l|l||}
\hline ArticleCopyright & $:$ & BioMed Central Ltd2004 \\
\hline \hline ArticleGrants & $:$ & \\
\hline \hline ArticleContext & $:$ & 13059551212 \\
\hline
\end{tabular}

\section{Chromosome pairing in Arabidopsis}

A selection of evaluations from Faculty of $\mathbf{1 0 0 0}$ covering chromosome pairing in Arabidopsis; hybrid inviability in birds and mammals; endogenous siRNAs in Arabidopsis; evolution of sex-biased genes in Drosophila; human patterns of genetic variation.

Chromosome territory arrangement and homologous pairing in nuclei of Arabidopsis thaliana are predominantly random except for NOR-bearing chromosomes. Pecinka A, Schubert V, Meister A, Kreth G, Klatte M, Lysak MA, Fuchs J, Schubert I. Chromosoma 2004, 113:258-269.

For the Faculty of 1000 evaluation of this article please see: http://genomebiology.com/reports/F1000/ gb-2004-5-12-360.asp\#Pecinka

\section{Hybrid inviability in birds and mammals}

Rates of evolution of hybrid inviability in birds and mammals. Fitzpatrick BM. Evolution Int $J$ Org Evolution 2004, 58:1865-1870.

For the Faculty of 1000 evaluation of this article please see: http://genomebiology.com/reports/F1000/ gb-2004-5-12-360.asp\#Fitzpatrick

\section{Endogenous siRNAs in Arabidopsis}

Endogenous trans -acting siRNAs regulate the accumulation of Arabidopsis mRNAs. Vazquez F, Vaucheret H, Rajagopalan R, Lepers C, Gasciolli V, Mallory AC, Hilbert JL, Bartel DP, Crété P. Mol Cell 2004, 16:69-79.

For the Faculty of 1000 evaluation of this article please see: http://genomebiology.com/reports/F1000/ gb-2004-5-12-360.asp\#Vazquez 


\section{Evolution of sex-biased genes in Drosophila}

Molecular evolution of sex-biased genes in Drosophila . Zhang Z, Hambuch TM, Parsch J. Mol Biol Evol 2004, 21:2130-2739.

For the Faculty of 1000 evaluation of this article please see: http://genomebiology.com/reports/F1000/ gb-2004-5-12-360.asp\#Zhang

\section{Human patterns of genetic variation}

Population history and natural selection shape patterns of genetic variation in 132 genes. Akey JM, Eberle MA, Rieder MJ, Carlson CS, Shriver MD, Nickerson DA, Kruglyak L. PLoS Biol 2004, 2:e286.

For the Faculty of 1000 evaluation of this article please see: http://genomebiology.com/reports/F1000/ gb-2004-5-12-360.asp\#Akey 